\title{
Corela
}

Cognition, représentation, langage

3-2| 2005

Vol. $3, n^{\circ} 2$

\section{The BE + -ING form: Progressive aspect and metonymy}

\section{Grégory Furmaniak}

\section{(2) OpenEdition}

1 Journals

Electronic version

URL: http://journals.openedition.org/corela/528

DOI: 10.4000/corela.528

ISSN: 1638-573X

\section{Publisher}

Cercle linguistique du Centre et de l'Ouest - CerLICO

\section{Electronic reference}

Grégory Furmaniak, "The BE + -ING form: Progressive aspect and metonymy », Corela [Online], 3-2 I 2005, Online since 27 December 2005, connection on 10 December 2020. URL : http:// journals.openedition.org/corela/528; DOI : https://doi.org/10.4000/corela.528

This text was automatically generated on 10 December 2020.

\section{(c) (i) (2)(2)}

Corela - cognition, représentation, langage est mis à disposition selon les termes de la licence Creative Commons Attribution - Pas d'Utilisation Commerciale - Partage dans les Mêmes Conditions 4.0 International. 


\title{
The BE + -ING form: Progressive aspect and metonymy
}

\author{
Grégory Furmaniak
}

\section{Introduction}

1 In his groundbreaking thesis published in 1978, H. Adamczewski was one of the first to question the aspectual meaning of the so-called English Progressive (a label he strongly rejected). Instead, he contended that BE + -ING is the imprint left by an abstract thought process and that the various semantic values of the form (such as duration, future time reference, intention, habit, etc.) result from the interaction of the context and of the mental process at work in the production of such utterances.

2 The aim of this paper is to suggest that the analysis of BE + -ING as an aspectual marker cannot be dismissed so easily, but also that the kind of cognitive processes described by Adamczewski can operate within a referential framework and must indeed be postulated if we are to account for the well-known Progressive meaning as well as other less-known uses of the form.

\section{Adamczewski's analysis of BE + -ING}

3 To start with, let us consider Adamczewski's arguments against the "Progressive hypothesis" and his own proposal, which served as the starting-point of his "Metaoperational Grammar" (whose leading hypothesis is that grammatical forms do not carry a set of semantic values or even a core-value, but codify abstract mental operations contributing to the construction of utterances - hence the name of "meta-operator" for markers like BE + -ING, HAVE + -EN, THE, A, SOME, etc.). Adamczewski's criticism of descriptive approaches is supported by real data taken from a large corpus which, from the outset, stamps former studies based on "made-up" examples as, at best, fragmentary, and at worst, unscientific. 
4 Adamczewski claims that relying on semantic criteria alone leads to an almost endless list of unrelated senses and exceptions. Mere description, he argues, should not be the ultimate goal of linguistics. What the linguist must aim at, he suggests, is an explicative account of grammatical phenomena. Moreover, he points out that some occurrences of $\mathrm{BE}+$ - ING, though grammatical and acceptable, invalidate descriptions based on aspectuality. Take, for instance, example (1).

(1) So when you vote for a candidate, you are voting also to endorse the whole system

http://www.progress.org/archive/fold128.htm

There seems indeed to be no obvious reason why BE + -ING is used in the second clause, given that, in the first clause, the same verb occurs in the Simple Present. According to Adamczewski, who analyses similar examples, $\mathrm{BE}$ functions as a relator between the subject and a VP marked as "given" or "thematic" by the -ING morpheme ${ }^{1}$. It means that the speaker uses $\mathrm{BE}+-\mathrm{ING}$ not to assert that the verbal happening is unfolding (it is not) but to provide further information about a predicate the hearer has already processed, given that it has just been mentioned. Thus, (1) conveys the speaker's personal comment on the implications of the event <vote for a candidate>.

Example (2) is another problem case for upholders of the aspectual theory.

(2) 'The house is a bit big for you now, isn't it?' He said.'Don't start on me, for the love of God. Tess is always nagging me to sell up and move into a flat. (David Lodge, Paradise News)

7 Not only does this example make reference to several occurrences of the same event, but it implies that this event is not taking place at the moment of speaking. In Adamczewski's theory, the event <nag me> is regarded as thematic in the sense that the speaker takes it for granted ${ }^{2}$ that the hearer knows the event to have already happened many times before. The "given" status of <nag me> is syntactically reflected by the nominalizing function of the -ING morpheme, since, according to Adamczewski, nominalization requires that the information be shared by both speaker and hearer (or presented as such). The "new" information in (2) is conveyed by the adverb always which takes on a modal function and enables the speaker to pass judgement on the recoverable information. Indeed, there is undoubtedly more speaker involvement in (2) than in (3).

(3) She always nags me to sell up and move into a flat.

8 In (3), the speaker, in a neutral way, presents the subject's habit as new information. By contrast, not only does (2) present the event as old information, but it conveys, though implicitly, the speaker's attitude towards it (it can be disapproval, irritation but also amusement).

9 It is a known fact that "certain verbs are rare in the continuous form" (Allen 1974: 99) but, more often than not, no reason is given as to when and why these verbs may be used in the BE + -ING form. Adamczewski (1996: 29) gives the following example and justifies the use of $\mathrm{BE}+-\mathrm{ING}$ along the same lines.

(4) For the first time, Bobby felt, he was really seeing the man.

10 First, the definite article in the NP the man suggests that the VP does not impart new information. Bobby had already seen the man before - hence the nominalization of the VP. Again, the BE + -ING form enables the speaker to draw on already processed information and to make a comment on it. It is not that Bobby saw the man that matters, but that he now saw him in a different way, as he really was. Adamczewski's analysis is 
corroborated by the fact that the tonic syllable of the last tone-unit falls on REAlly. What comes next is of low information value.

11 As is evidenced by example (5), verbs in the Progressive Present may also have future time reference.

(5) George is coming back on Monday (quoted in Adamczewski 1996: 30)

12 Once more, the inadequacy of the aspectual analysis seems to be patent. The event is obviously not in progress at the moment of speaking, since it has not even started yet. Adamczewski's hypothesis is that the VP come back is nominalized and that the information it conveys is thematic. This is why examples such as (5) are likely to be interpreted as referring to a fixed arrangement. In (5), the information-providing element - if any - is the adverbial on Monday which indicates the date of George's planned return.

13 In fact, given the kind of cognitive process underlying the use of the Progressive form, it is often the case that the speaker uses BE +-ING as part of a rhetoric strategy. In example (5), for instance, the hearer may not be aware that George is coming back at all. But by presenting George's return as "given", the speaker pretends s/he thinks that the hearer knows that George is coming back. The event thus appears to the addressee as a fait accompli.

We are aware that this brief summary is not doing justice to Henri Adamczewski's theory, but our aim was just to provide the reader with the outlines of a study which had a huge impact (at least in France) and which is still hotly debated. Yet, it must be said that, today, few linguists adhere to the theory as it was originally stated. The reasons for this, some of which we are now going to examine, are probably linked to the author's extreme views on some topics (for example, his insistence that the referent of the subject is never agentive).

\section{Problems with Adamczewski's analysis}

Our aim is not to provide a detailed criticism of Adamczewski's account of $\mathrm{BE}+-\mathrm{ING}^{3}$, but to point to some of its deficiencies.

16 First of all, the nominalizing function of -ING is not as obvious as Adamczewski would have it. He is completely justified in saying that nominalization is undeniable in examples like (6) and (7).

(6) The singing of the birds.

(7) People came here because of the climate and lay about in the sun all day. It was

asking for trouble. (David Lodge, Paradise News)

In (6), singing could be replaced with song with little change of meaning. In (7), anaphoric it refers back to the previous sentence which is equated with the NP asking for trouble. The second sentence may therefore be reworded as:

(7') Laying about in the sun all day was asking for trouble.

18 Two points must be made in connection with this sentence. First, the two NPs are on an equal footing and the auxiliary be functions as an equal sign. Furthermore, asking for trouble may be replaced with an NP like a mistake. The rub is that (7) and (7') are not instances of the Progressive form, and what is true of the gerund in (7) is not true of $\mathrm{BE}+$ ING. Compare with (8): 
(8) People came here because of the climate and lay about in the sun all day. They were asking for trouble. more precise, Progressive. By "Progressive", we mean that the event is viewed as in progress at a given moment. In example (10), the event <Mary-write a book $>^{4}$ is said to have started prior to the present moment (henceforth noted $\mathrm{T}_{0}$ ) and to be as yet uncompleted.

(10) Mary is writing a book.

In most cases, the Progressive meaning is not only sufficient to account for the use of the $\mathrm{BE}+-\mathrm{ING}$ form but also to rule out the Simple Present. The only suitable means for the speaker to refer to an event ${ }^{5}$ occurring in the present situation is the BE + -ING form. (11) is odd :

(11) * Mary writes a book.

and (12) expresses a habit, which, according to Vendler (1967: 108), is also a state, not an event.

(12) Mary writes books.

Of course, the aspectual function of the BE + -ING form is not always as obvious, and some adjustment may be necessary. But we argue that the differences in the meaning of $\mathrm{BE}+-$ ING depend on two parameters; namely: the type of predicate involved and the nature of the reference point at which is the event is said to be in progress. 


\subsection{BE + -ING and states}

27 First of all, our claim is that BE + -ING only applies to events, not states. This may sound paradoxical in the light of sentences such as (13).

(13) Stella tells him he is being stupid and goes out to the porch. ( www.novelguide.com)

But one must distinguish between a verb, or rather, a verb phrase, and what it refers to. Because of its lexical meaning, a VP like be stupid normally denotes a state but it can, in certain circumstances, refer to an event. So, the incompatibility that has been noted by many linguists is not between BE + -ING and VPs like be stupid, but between BE + -ING and the reference to states, and it lies therefore not at the lexical level but at the level of conceptual representations. In (13), the VP be stupid has undergone a shift in meaning. The semantic conflict arising from its usual stative meaning and the use of BE + -ING is resolved by an alteration of the basic meaning of the VP. Instead of signifying the property ${ }^{6}$ of being stupid, it now refers to the characteristic behaviour of a stupid person. (13) means therefore: He is acting like a stupid person ${ }^{7}$. This kind of semantic shifts is systematic when a so-called "state-verb" is used in the Progressive form. The VP stops expressing a property to denote an activity which is either the result or the observable manifestation of this property. To show this a little more clearly, let us examine example (14).

(14) Don't worry so much. Those kids are learnin', in spite of you."

I feel suddenly disappointed.

"I sense that you're not believing me. Okay. Forget the kids-leave 'em alone." (

http://www.missourireview.com)

Believe belongs to the class of "verbs of inert cognition" (Leech 1987: 25). As such, it is "passive in meaning" (ibid.) and may therefore be seen as expressing a state (a state of mind, to be accurate). The Simple Present would naturally be possible, but in (14), the stress is not so much on the narrator's disbelief as on the visible signs of his/her disbelief. The verb sense plays a prominent part in emphasising that the speaker can perceive the outward manifestation of the narrator's doubts.

The only remaining question is: Why does the BE + -ING form admit only reference to events and not to states? This restriction in the use of the Progressive is closely linked to what Comrie (1976: 3) calls the "internal temporal constituency" of events and states. However, we reject Palmer's claim that "the sense of duration is an integral part of the lexical meaning of the [stative] verb, and [that] there is for this reason no need for a Progressive form to indicate duration" (Palmer 1974:73). Indeed we may wonder on what grounds Palmer makes the assumption that states are inherently durative when everything points to the contrary.

31 Take an event like <write a letter>. It is durative because it requires several instants (an instant being defined as the minimal time-unit) before it has reached its completion and completeness. The distinction between those two concepts wants explaining. We shall speak of completion when an event or a state is over, completion being defined as "the state of being complete and finished" (Oxford Advanced Learners' Dictionary). The telic ${ }^{8}$ event <write a letter> is therefore completed when the end-point has been reached and the letter is written. An atelic ${ }^{9}$ event such as <write $>$ is completed once the agent has put an end to it. A state is completed when it ceases to be true. The notion of completeness is 
slightly more difficult to explain. The dictionary (ibid.) provides us with the following definition: "including all the parts that are necessary". In fact, an event must be conceived as a succession of different compulsory parts or phases, and it is complete if and only if the subject has gone through all of its phases.

Let us take a simplified example. We shall assume that the event <write> is composed of three different phases which, of course, can - and often do - repeat themselves in the same order : (i) < put a pen on paper>, (ii) <draw letters>, (iii) <move hand to the right>. If the agent stops after having accomplished (i) and (ii), what $s /$ he has done cannot be called writing, whereas if s/he stops after (iii), the activity may be described as writing and the event denoted by the verb is complete.

To sum up, a telic event attains completion (i.e. is completed) and completeness (i.e. is complete) once it has reached its end-point. An atelic event is completed when it has been interrupted and is complete when all of its compulsory phases have occurred at least once.

What about states? As noted earlier, they are completed when they cease to be true. But when are they complete? Following in the footsteps of A. Joly and D. O'Kelly (1990) and C. \& F. Recanati (1999), we contend that a state is complete as soon as it becomes true, that is from its very first instant of validity. Indeed, as Lyons (1977: 483) puts it: "a static situation (or state-of-affairs, or state) is one that is conceived as existing, rather than happening, and as being homogeneous, continuous and unchanging throughout its duration." Thus, a state is composed of just one homogeneous phase which repeats itself when the state is durative (but it need not be; and this is why we disagree over the term "continuous" used by Lyons).

In order to show that a state is complete after just one instant of existence, let us take another simple example. Imagine that a man died just after learning that he had won the lottery. Of course, he was not rich for very long, but for this short moment, he undeniably possessed the full property of being rich. This short period of time was enough for the state $<$ he-be rich> to be true and complete.

It is easy then to understand why BE + -ING cannot be used with states. Presenting a situation as in progress at $\mathrm{T}$ implies that the situation is, as it were, divided into two parts. One part is said to have been accomplished, the second to be uncompleted. This is possible with events because they consist of several phases ${ }^{10}$. But a state being made up of just one block is, as a result, undividable and therefore incompatible with the Progressive meaning and the BE +-ING form.

\subsection{BE + -ING and habituality}

However, it is sometimes argued that the Progressive can be used to refer to "a habit in existence over a limited period" (Leech 1987: 32), as in example (15):

(15) This year she is teaching English in Guangzhou, China, through the Princeton-in-Asia program. (www.princeton.edu)

If, following Vendler (see above), we are right in assuming that habits are categorized as states, then either our analysis of BE + -ING is inadequate or (15) does not make reference to a habitual situation.

In fact, the problem with Leech's description is that it is based on a very loose and intuitive notion of habituality. Yet, G. Kleiber (1987) has shown that it is possible - and 
desirable - to use the word habit in a narrow and technical sense so as to distinguish between habitual, iterative and frequentative sentences.

First of all, only habits are genuine states (Ibid. 206). So if we contrast (15) with (15a), only the latter can be rewritten as (15b), as it feels wrong to describe the subject in (15) as an English teacher.

(15a) She teaches English at Trinity Western University and Education at Simon Fraser University. (http://cybrary.uwinnipeg.ca)

(15b) She is an English teacher.

Secondly, according to G. Kleiber (1987: 200), for an event to be habitual, it must be: (i) iterated, (ii) regular and (iii) permanent (i.e. the period of time for which the habit holds should have sufficient extension for the repetition not to be considered as accidental). This, of course, deals a blow to the very notion of "temporary habit" implied by Leech's description (see above). Following G. Kleiber's criteria, if a situation is iterated and regular but not permanent, the sentence is frequentative. And indeed, this seems to be the case in (15). Unlike (15a), which meets all the criteria for habitual sentences, (15) is clearly temporary, as is made clear by the adverbial this year. Therefore, given that it does not express a habit, (15) does not contradict our hypothesis that BE + -ING cannot be used with states.

Nevertheless, we would like to account for the frequentative meaning of (15) and for the function of the Progressive form in such contexts. We contend that the role of BE + -ING remains unchanged. In (15), the situation <She - teach English> is said to have started prior to the moment of utterance. There is however a difference between (15) and (15c):

(15c) - Where's John?

-He's teaching.

In (15c), the situation is actually in progress at $T_{0}$. By contrast, in (15), the event is discontinuous and is therefore not necessarily taking place at speech-time. By discontinuous, we mean that the situation is not true at every moment of the interval. Discontinuity is of course a necessary condition for iterativity (cf. Kleiber 1987: 151), since to be iterated, an event must be interspersed with breaks; otherwise it is continuous.

So the extension of the temporal interval is essential to determine whether the situation is discontinuous or not. In (15c), it is because the context implies that the time span is quite short that the situation can be interpreted as continuous. To be more precise, the length of the time interval should be considered in relation with the usual (or normal) duration of a single uninterrupted occurrence of situations of the type described by the VP. In example (15), the time-frame of one year is obviously too large for an event such as $<\mathrm{He}$ - teach $>$ to take place continuously - we know indeed that an occurrence of teaching rarely exceeds a couple of hours at a stretch. The continuous interpretation of (15d) would be more likely insofar as it is possible for a situation like <exports - grow> to be continuous over a long period of time ${ }^{11}$.

(15d) After adjusting for price changes, merchandise exports are growing this

year, after plunging in 2001 and showing no growth in 2002. ( www.businessweek.com)

Yet if discontinuity is a necessary condition for the frequentative meaning to emerge, it is not a sufficient one. The aspectual properties of the event have also to be taken into account. If, in (15), we substitute a telic verb for the atelic predicate <teach English>, the discontinuous sense persists but the frequentative meaning vanishes. Consider (15e):

(15e) This year he is writing a book about China. 
46

Because the time interval is longer than the "normal" duration of a writing session, the situation is likely to be seen as discontinuous ${ }^{12}$. Yet (15e) is not frequentative, as it does not refer to the same "thing" happening over and over again during the time span. The difference between (15) and (15e) comes from the fact that telic events are heterogeneous, while activities (atelic) are homogeneous (cf. Recanati 1999: 178) ${ }^{13}$. This means that a telic situation is made up of qualitatively different phases, whereas atelic situations consist of qualitatively identical phases. Consider the following representation of a discontinuous situation in progress at the moment of speaking.

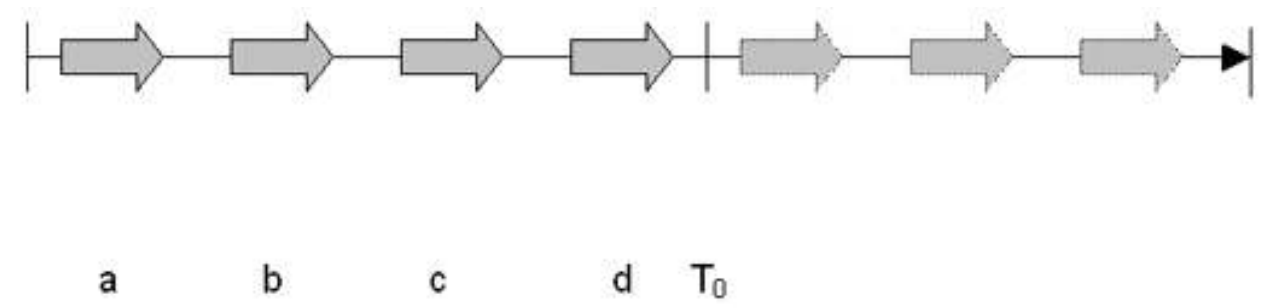

It is obvious that if phases $a, b, c$ and $d$ are qualitatively different, we do not feel as if the same event is iterated. By contrast, if $a, b, c$ and $d$ are qualitatively identical (as is the case with activities), then we do have the impression that the same event is happening over and over again, hence the frequentative meaning in (15).

In (15), $\mathrm{BE}+-\mathrm{ING}$ thus indicates that the situation is in progress at $\mathrm{T}_{0}$, but, owing to the extension of the time-frame (and to the meaning of the VP), the situation is viewed as discontinuous. Furthermore, because the event is atelic and composed of identical phases, saying that the same situation is alternatively interrupted and resumed or saying that we have several new occurrences of the event amounts to the same thing.

But if the meaning of (15) is frequentative, what then differentiates it from (15f), which is also undeniably frequentative?

(15f) This year she teaches English and Creative Writing. (http://fhs.gis.net)

Indeed, because the interval is too short, (15f) cannot be described as habitual. It therefore meets only criteria (i) and (ii), and must be regarded as frequentative. Consequently, we assume that from a strictly referential point of view, (15) and (15f) have the same underlying semantic representation. The two utterances only differ in the ways they construct the frequentative sense. As we have seen, in (15), it stems from the combination of the features [+ discontinuous], [+atelic] and [+progressive]. In (15f), because <teach English and Creative writing> is not the kind of situation that can be true and complete at speech-time (unlike an event such as score, it is not instantaneous), it is interpreted, owing to the Simple Present ${ }^{14}$, as a situation iterated over the whole interval. And because the time-frame is too restricted for the iteration to be considered permanent, the sentence is frequentative and not habitual.

\subsection{BE + - ING and genericity}

Having accounted for the incompatibility of the Progressive with states, let us now return to our analysis of the BE +-ING form as an aspectual marker. The use of the Progressive exemplified by (16) differs from (10) in that the reference point at which the event is said to be happening is not $T_{0}$ but an indeterminate point we shall note $T_{x}$. 
(16) This dog really needs help. He appears to have a bad case of mange. Half of his hair is gone and whenever I see him, he is scratching himself ferociously. ( www.nola.com)

(16) may indeed be paraphrased as :

(16') Whatever $\mathrm{T}_{\mathrm{x}}$ such as $<\mathrm{I}-$ see him $>$ is true at $\mathrm{T}_{\mathrm{x}}$, <he - scratch himself

ferociously> is in progress at $\mathrm{T}_{\mathrm{x}}$.

This shows that the meaning of $\mathrm{BE}+-\mathrm{ING}$ remains unchanged. The overall meaning of the utterance is modified because the reference point is now generic, and consequently, the event is not taking place in the present situation but in every situation of the type described in the subordinate clause.

If this claim is correct, the problem raised by utterances like (2) is easily solved.

(2) 'The house is a bit big for you now, isn't it?' He said.

'Don't start on me, for the love of God. Tess is always nagging me to sell up and move into a flat. (David Lodge, Paradise News)

The function of the adverb always is similar to that of the subordinate clause in (16). It refers to an indeterminate reference point $\mathrm{T}_{\mathrm{x}}$ at which the event $<$ Tess-nag me to...> is said to be in process. However, here, $\mathrm{T}_{\mathrm{x}}$ is not restricted to a definite situation-type. (2) may indeed be paraphrased as :

(2') Whatever $\mathrm{T}_{\mathrm{x}},<$ Tess - nag me to... $>$ is in progress at $\mathrm{T}_{\mathrm{x}}$.

The gloss implies that the event is constantly in progress, at any moment. This is of course an exaggeration and it may explain, in a very simple way, why these utterances are often felt to be highly subjective and to express the speaker's attitude towards the event. We may also add that, along with the intonation, the choice of the verb plays a prominent part in signalling the speaker's disapproval. This is probably why the emotional involvement of the speaker is less strongly felt in (17) as, the VP spend time together does not carry any negative connotation, unlike the verb nag.

(17) "He and I are always spending time together but we are not romantically inclined", she said (BNC)

\subsection{BE + -ING and future time reference}

Let us now turn to example (5). As we said earlier, (5) is more difficult to account for in terms of Progressive aspect, since the event <come back> has not started at $\mathrm{T}_{0}$.

(5) George is coming back on Monday (quoted by Adamczewski 1996: 30)

But once more, the internal temporal structure of the event has to be taken into consideration. <come back> belongs to the same class of events as <leave>. Vendler (1967: 102) calls them "achievements" 15 . At first sight, they look like instantaneous events. As a matter of fact, a verb like leave refers to the transitional point between two states : <be here> and <not be here>. Yet, the analysis of achievements as instantaneous events is counter-intuitive. What is actually denoted by leave is just the last stage of an implicit event. This observation has led C. and F. Recanati (1999) to consider that a verb like leave refers to a durative event whose terminative point is focalized. Example (5) can therefore be analysed as expressing Progressive meaning. But what is in progress at $T_{0}$ is not the focalized point explicitly denoted by the VP, but the implicit process that leads to it.

We must be careful to distinguish this use of BE + ING from the one illustrated by (18), which also has future time reference. 
(18) It won't be long until we are knocking on the door to get back to the Premier League. (Web Concordancer, The Times, January 1995) future by the embedding clause. So, the difference in meaning is not due to BE + -ING itself but to the location of the reference point in the future.

\subsection{BE + -ING and re-interpretation}

is point, we have managed to account for all the uses of aspectual terms by making allowance for two variables: the lexical meaning of the VP and the reference point. Yet, a problem occurs when it comes to analysing examples like (1) and (19-20).

(1) So when you vote for a candidate, you are voting also to endorse the whole system. (www.progress.org/archive/fold128.htm)

(19) When a girl of twenty-four marries a man close to eighty, it is obvious that she is marrying him for money. (Quoted by Adamczewski 1978: 71)

(20) When she says she took the money, she is lying with the idea of shielding Captain Paton. (Quoted by Adamczewski 1978: 110)

61 This use has been alternatively described as "anaphoric" (Adamczewski 1978), "reinterpretative" (Girard 1998) or "implicative" (Boisson 2004), in the sense that the proposition in the main clause refers back to, re-interprets, or is implied by the proposition in the subordinate clause. As we pointed out earlier about (1), this use of the $\mathrm{BE}+-\mathrm{ING}$ form does not seem to be a matter of aspect. Moreover, in all these examples, the Progressive Present can be substituted with the Simple Present with little change of meaning. See (9) above, and consider (19') and (20a).

(19') When a girl of twenty-four marries a man close to eighty, it is obvious that she marries him for money.

(20a) When she says she took the money, she lies with the idea of shielding Captain Paton.

The acceptability of (19') and (20a) could be discussed further but it would be unjustified to rule them out as ungrammatical. It could be, therefore, that the opposition between the Progressive Present and the Simple Present is neutralised in this context.

Yet, two objections can be made. First, the Progressive is intuitively felt to be more subjective. Secondly, this "re-interpretive" use seems to transcend other semantic distinctions, since data suggest that it may be combined with some of the uses we discussed earlier. Take (21), for instance.

(21) I hope I am transgressing no professional etiquette in questioning you on the subject. (quoted by Adamczewski 1978: 146)

Though syntactically different from previous utterances, (21) is a perfect example of reinterpretation. The speaker hopes that $<\mathrm{I}-$ question you $>$ does not equate with $<\mathrm{I}-$ transgress [some] professional etiquette>. But at the same time, the meaning of BE + -ING is undeniably Progressive, and the Simple Present is not permitted. (21') is indeed ungrammatical unless it refers to a habit:

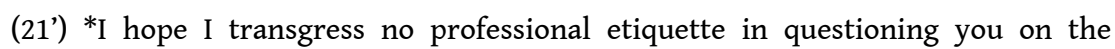
subject.

Therefore, what makes it particularly awkward to differentiate the Simple Present from the Progressive Present in (1) and (19-20) is the fact that these sentences are either generic or habitual and that no reference point is mentioned or recoverable. Indeed, the 
role of the subordinate clause is not to provide the main clause with a reference point at which the event can be said to be in progress. Compare (20) and (20b).

(20) When she says she took the money, she is lying with the idea of shielding Captain Paton.

(20b) When she says she took the money, she smiles.

When she says she took the money could be understood as an answer to the question: When does she smile? , but not to: when does she lie? or: when is she lying? The reason is that in (20) both clauses refer to the same event, so it would be absurd to argue that <she - lie> is in progress at the instant at which she says she took the money. This does not mean, however, that the subordinate clause in (1) and (19-20) has no temporal function. It does indeed locate the event of the main clause in time. To be precise, the subordinate clause refers to a situation-type in which the second event is true. We could even argue that the event <she - lies is said to be in progress at any indeterminate instant within the situation-type whenever the latter is actualised. So far, so good. But does this really help us to distinguish (20) (she is lying) from (20a) (she lies)? In a way, it does. When the reference point is neither explicit nor recoverable, the difference between the two verbforms becomes blurred, while when the reference point is explicit or recoverable (as in (21) where it is identical to $T_{0}$ ), the two forms are no longer interchangeable. If you replace the verb say in (20) with another verb unrelated to the act of saying, then the two VPs no longer denote the same event, the subordinate clause serves as a reference point, the Progressive meaning becomes patent, and the Simple Present is not permitted. This appears clearly in (20c):

(20c) When she smiles, (you can tell) she is lying.

Nevertheless, the fact that, in (20), there is indeed an indefinite point at which the event is in progress should not be neglected. Given that the Simple Present (as in she lies) refers to the event as a whole without taking its internal structure into account, what matters is its completion. But with the BE + -ING form, whether the reference point be explicit or not, we are viewing the event "from the inside", and we are therefore concerned not with its completion but with its completeness. This means that with the Progressive form, the focus is not on the occurrence of the event but on its internal structure, that is on its characteristics $^{16}$, on the properties that make the happening an instance of the action denoted by the VP. Such focus on the properties of the event rather than on its actual occurrence is in harmony with the sense of re-interpretation, since re-intepretation has to do with the search for a better word to describe a given situation. However, this explains why the two verb-forms may be used almost indifferently in this context because, in the same way as BE +-ING, despite the focus on the characteristics of the event, also refers to its occurrence, the Simple Present, though it emphasises the occurrence of the event, necessarily refers to its characteristics.

68 As we have seen, the last three examples are more difficult to explain in terms of aspectuality. Yet, we have tried to show that this use is not unrelated to the Progressive meaning. Should we conclude then that Adamczewski's hypothesis must be discarded completely? We do not think so. First, because we believe that the emphasis on the characteristics of the event is not the only reason why BE +-ING is used in the so-called anaphoric utterances. Besides, we claim that the Progressive meaning is a complex semantic construct resulting from an abstract mental process similar to the one described by Adamczewski. Furthermore, we suspect that, in the case of re-interpretation, BE +-ING 
is used because of this underlying cognitive process more than for its aspectual function (though the latter, as we have argued, is not totally erased).

\section{How is the Progressive meaning constructed?}

The Progressive meaning is in fact more complex than it appears. When a speaker asserts that an event is taking place, we might think that $\mathrm{s} / \mathrm{he}$ is simply describing what $\mathrm{s} / \mathrm{he}$ perceives. But on second thoughts, it must be realised that the speaker is in fact basing his/her assertion on another proposition. This is quite obvious in the "re-interpretive" use examined above, but may be generalised to all the uses of the BE +-ING form.

\subsection{BE + -ING and inference}

In many examples, the proposition expressed by the clause containing BE + -ING (henceforward P) is inferred from another proposition $(\mathrm{Q})$ which may or may not be explicit. This is exemplified by (22) where the verb infer makes explicit the referential process which leads Sue from the observation of the man's glare to the assertion of $P$.

(22) By the glare which he directs at herself, Sue infers that he is waiting for her to disappear before he enters the cubicle. She returns to her seat next to Dee, who is reading a courtesy copy of Cosmopolitan. (David Lodge, Paradise News)

The proposition $\mathrm{Q}$, which serves as the basis for the inference, is taken from the context, and more precisely, from the situation. According to Sperber and Wilson (1995: 141), there are three possible sources for contextual assumptions: (i) "the physical environment", (ii) the interpretation of previous utterances and (iii) encyclopaedic knowledge. Like (22), (23) also refers to the physical environment, since the event <it rain> is clearly inferred from a contextual assumption such as: I can see drops of water, the role of the verb look being to draw the attention of the addressee to the origin of the assumption.

(23) In Scotland, I would wake up every morning, open the curtains and say, 'Ôoh look it's raining, what a surprise!' (www.clarku.edu/alumni/clarknews/)

(24) shows that the inference may also be based on an assumption derived from the interpretation of preceding utterances. What Bernard has just said is so surprising that the speaker infers that Bernard is kidding. The meaning is therefore almost the same as in: You must be kidding.

(24) 'Let's go, then. I have my car in the lot outside. You guys must be exhausted, huh?' She addressed the question particularly to Mr Walsh.

I was exhausted in Los Angeles,' said Mr Walsh.' I don't know the word for what I am now.'

'It was his first flight,' Bernard said.

'No! You're kidding!' Well, I think it's just wonderful, Mr Walsh to come all this way to see your poor sister.' (David Lodge, Paradise News)

In (25), the assertion of P rests on assumptions that partake of the speaker's and hearer's encyclopaedic knowledge.

(25) You see, Bush is trying to protect American Republicans and Democrats alike. That's his job. Kerry has not projected that plan remotely. This should frighten you. (www.bigpumpkins.com/msgboard)

73 You see acts here as an implicit reminder of what Bush is known to have done and said, and the contextual assumptions (shared by the speaker and hearer) thus conjured up are used by the speaker to infer $P$. 

$\mathrm{Q}^{17}$ do not have the same informational status. $\mathrm{Q}$ is indeed "given" or, in the terminology of Relevance Theory, "manifest" to the hearer (or presented as such) ${ }^{18}$. An assumption is "manifest to an individual if and only if he is capable at that time of representing it mentally and accepting its representation as true or probably true" (Sperber \& Wilson 1995: 39). This notion of manifestness is useful because it is, as Sperber and Wilson argue (1995: 40), "weaker than the notion of what is actually known or assumed". In some cases, the hearer may actually know that $\mathrm{Q}$, but in other cases, as in the look it's raining example, $\mathrm{s} /$ he may not have noticed that $\mathrm{Q}$. But the point is that $\mathrm{Q}$ is easily accessible. By contrast, it would be tempting to consider P as "new" information. After all, it is presented as the result of an inference being carried out on the spot by the speaker. Yet, this argument would be all-too easy to counter. Consider (26):

(26) Ok as you guys will remember Bush is trying to come off as optimistic. ( www.georgewbush.org/forum) difficult to speak of inference here. Similarly, in (27), while the speaker indeed reanalyses Q (it's good PR to subsidize a bit of academic research) as P (I'm doing to tourism what Marx did to capitalism...), he does not infer $\mathrm{P}$ from $\mathrm{Q}$.

(27) '(...) The British Association of Travel Agents are paying for it. They think it's good PR to subsidize a bit of academic research now and again. Little do they know.' He grinned mirthlessly again.

'What d'you mean?'

'I'm doing to tourism what Marx did to capitalism, what Freud did to family life. Deconstructing it. (David Lodge, Paradise News)

\subsection{From inference to metonymy}

This shows that inference cannot be postulated in all cases. Yet, the fact remains that $\mathrm{P}$ and $\mathrm{Q}$ are semantically connected, since intuitively, we sense that a proposition such as I can hear a bang $(\mathrm{Q})$ could lead the speaker to utter Someone's knocking $(\mathrm{P})$, whereas I can hear music would not. What then is the semantic link between the two propositions? Girard (1998) considers that the relationship is synecdochic, as P refers to a part of Q, the whole. In example (1), which we repeat for the sake of clarity, voting for a candidate implies, or better, includes voting to endorse the system.

(1) So when you vote for a candidate, you are voting also to endorse the whole system. (www.progress.org/archive/fold128.htm)

But we think that the semantic link between $P$ and $Q$ is in fact not limited to synecdoche. Consider again example (14):

(14) Don't worry so much. Those kids are learnin', in spite of you."

I feel suddenly disappointed.

"I sense that you're not believing me. Okay. Forget the kids-leave 'em alone." (

http://www.missourireview.com)

As we have seen, the speaker relies on what he perceives in order to assert the truth of $<$ you -not believe me>. But <I - feel you are disappointed>, or any similar proposition, cannot be regarded as a part of <you - not believe me>. We would rather say that $Q$ is an 
effect of P. We shall therefore argue that the semantic relationship between $Q$ and $P$ is fundamentally metonymic. with the name of something else closely associated with it" (Baldick 1990: 135). Yet, as we are not dealing with figures of speech, we shall be using the term "in a wider sense, to designate the process of association by which metonymies are produced and understood: this involves establishing relationships of contiguity between two things" (ibid.), here, between two propositions. Synecdoche is therefore just one of the many forms metonymy may assume. In his Dictionnaire de la linguistique (1995: 215), Mounin gives a list of possible realisations of metonymy. We believe that the following types of metonymy are relevant here: part/whole, cause/effect, appearance/reality and content/container.

The part/whole relation has already been mentioned. Nevertheless we shall not apply it to examples like (1) but to cases where $Q$ refers to the knowledge that a part of the event has already taken place. In (28), for instance, the speaker has decided on her own that she and here husband are going to the beach. Her decision to go to the beach (Q) is sufficient for her to assert $\mathrm{P}$, given the synecdochic relationship between the two propositions (the decision to do something is part of the action itself). The speaker thus builds the representation of the whole event on the knowledge that a part of it has occurred.

(28) It has been a trying day for Russ. Cecily showed considerable ingenuity in avoiding direct communication with him. In the morning, she called the concierge from their room to say, "We're going to the beach, which part would you recommend?" so that when she prepared to go out, Russ knew where she was going. (David Lodge, Paradise News)

Similarly, the speaker in (2) knows that the event <Tess - nag me to sell up...> has already occurred several times, and from this knowledge, he extrapolates <Tess - always nag me to sell up...>, the individual occurrences of $Q$ being constitutive of the iteration expressed by $P$.

(2) 'The house is a bit big for you now, isn't it?' He said.'Don't start on me, for the love of God. Tess is always nagging me to sell up and move into a flat. (David Lodge, Paradise News)

But in fact, the most current relationship between $Q$ and $P$ is one of effect and cause, where $Q$ is the manifest effect of P. (14), (19) and (22) belong to this category.

(14) Don't worry so much. Those kids are learnin', in spite of you."

I feel suddenly disappointed.

"I sense that you're not believing me. Okay. Forget the kids-leave 'em alone." ( http://www.missourireview.com)

(19) When a girl of twenty-four marries a man close to eighty, it is obvious that she is marrying him for money. (quoted by Adamczewski 1978: 71)

(22) By the glare which he directs at herself, Sue infers that he is waiting for her to disappear before he enters the cubicle. She returns to her seat next to Dee, who is reading a courtesy copy of Cosmopolitan. (David Lodge, Paradise News)

Logically, most of the utterances where an inferential process is apparent fall within this category. This is not surprising insofar as when an effect $(\mathrm{Q})$ is visible, very often, its cause $(\mathrm{P})$ is not and is therefore a matter of guessing. Thus, in (14), the signs of disappointment are interpreted by the speaker as the effect of the narrator's doubts. In (19), marriage between a young woman and an old man is regarded as motivated by selfinterest. And in (22), Mr Walsh's glare directed at Sue reflects his desire to see her leave. 
However it may be, examples (21) and (1) suggest that the effect/cause relationship may be reversed. In (21), for instance, $<I$ - transgress (some) professional etiquette $>(P)$ is presented as a possible, though unwanted, effect of < (I) - question you>. Similarly, <you vote to endorse the whole system $>(P)$ is the consequence of $<y o u$ - vote for a candidate $>$ (Q).

(21) I hope I am transgressing no professional etiquette in questioning you on the subject. (quoted by Adamczewski 1978: 146)

(1) So when you vote for a candidate, you are voting also to endorse the whole system. (www.progress.org/archive/fold128.htm)

There is a risk of overlap between the appearance/reality link and the effect/cause relationship. In order to maintain a clear-cut distinction, we shall assume that within this category, what appears to be true (i.e. $Q$ ) is actually false. The speaker therefore asserts $P$ so as to rectify, as it were, a false assumption that is manifest to the hearer, either because it has been mentioned before or because it seems to be true. This is exemplified by (27).

(27) '(...) The British Association of Travel Agents are paying for it. They think it's good PR to subsidize a bit of academic research now and again. Little do they know.' He grinned mirthlessly again.

'What d'you mean?'

'I'm doing to tourism what Marx did to capitalism, what Freud did to family life. Deconstructing it. (David Lodge, Paradise News)

The assumption rejected by the speaker is the belief that subsidizing his research is good PR for the British Association of Travel Agents. It is rectified by I'm doing to tourism what Marx did to capitalism as is evidenced by the possibility to add the adverbial in fact, whose role is "to emphasize a statement, especially one that is the opposite of what has just been mentioned" (Oxford Advanced Learners' Dictionary). Indeed, (27) implies:

(27') They think it's good PR, but in fact, I'm doing to tourism what Marx did to capitalism.

89 Let us now move on to the content/container relationship, which we restrict to the meta-linguistic description of utterances. The container is taken to refer to the illocutionary act of a sentence, and the content to the sentence itself. Austin (1976: 98-99) defines illocutionary acts as follows:

"To perform a locutionary act is in general, we may say, also and eo ipso to perform an illocutionary act [...] Thus in performing a locutionary act we shall also be performing such an act as :

asking or answering a question,

giving some information or an assurance or a warning,

announcing a verdict or an intention,

prononouncing sentence,

making an appointment or an appeal or a criticism,

making an identification or giving an assumption,

and the numerous like."

Although illocutionary acts may be explicit (as in he asked me if I knew the answer), in direct speech, they often remain implicit. However, BE + -ING is sometimes used to refer back to the illocutionary act (the container) of a sentence (the content) that has just been uttered. Consider (29):

(29) A: Is anything the matter, Jeremy?

B: What do you mean, Frances?

A: I'm asking you if there is anything the matter. (quoted by Adamczewski 1982:

58) 
91 Is anything the matter, Jeremy?). The speaker therefore relies on $\mathrm{Q}$, the content, to assert $\mathrm{P}$, the container.

It is tempting to include examples like (20) and (24) in this category, since predicates such as lie, kid, but also tell the truth or tell a lie seem to denote illocutionary acts. Yet, the specificity of these verbs has already been noted by Austin (1976: 104) who prefers to speak of "use of language" to describe their meaning and function. As he points out (ibid.):

"let us be quite clear that the expression 'use of language' can cover other matters even more diverse than the illocutionary and perlocutionary acts and obviously quite diverse from any with which we are here concerned. For example, we may speak of the 'use of language' for something, e.g. for joking; and we may use 'in' in a way different from the illocutionary 'in', as when we say 'in saying " $p$ " I was joking' or 'acting a part' or 'writing poetry'. These references to 'use of language' have nothing to do with the illocutionary act."

Let us examine (20) ${ }^{19}$.

(20) When she says she took the money, she is lying with the idea of shielding

Captain Paton. (quoted by Adamczewski 1978: 110)

If the verb lie referred to an illocutionary act, the content of what has been said (i.e. she took the money) would have to be repeated, as it is in example (29). Consequently, we think that example (20) is another instance of the appearance/reality relationship. As a matter of fact, $\mathrm{P}$ comes as a surprise, since you are not expected to lie, especially when you accuse yourself. (20) can be paraphrased as:

(20d) She says she took the money, but she is lying.

Conjunction but is known to convey "adversative meaning" (Halliday \& Hasan 1976: 250), which means that the clause it introduces is presented as "contrary to expectation" (ibid.). But why is <she - lie> unexpected? We believe this has to do with Grice's "Maxims of Quality", and more particularly with: "Do not say what you believe to be false" (Grice 1975: 47). When someone says something (e.g. "I took the money"), the hearer assumes that the speaker is being cooperative and that $\mathrm{s} / \mathrm{he}$ is telling the truth, as any utterance implicitly conveys the presupposition of its own veracity. So in (20), she is lying may be interpreted as contradicting the presupposed truthfulness of $Q$. This is of course reminiscent of the process of rectification at work in the case of appearance/reality relationships. Not surprisingly, she is telling the truth is far less frequent in this context than she is lying or she is telling a lie. The reason is that she is telling the truth implies that $\mathrm{Q}$ was expected to be false. This is possible only if the subject is known as a confirmed liar or if $Q$ is actually so unbelievable as to seem untrue. Consider (20e):

(20e) When she says she was abducted by aliens, she is telling the truth.

The first clause would normally lead the hearer to conclude that the referent of she is lying. But the main clause is meant as a denial of this inference.

\subsection{From metonymy to Progressive aspect}

Having thus established that the proposition expressed by an -ING clause entertains a metonymic relationship with an assumption that is manifest to both the speaker and the hearer, it remains for us to show that not only are metonymy and Progressive aspect 
related, but that Progressive meaning cannot be constructed independently of a cognitive process which consists in basing one's assertion that $\mathrm{P}$ is in progress at $\mathrm{T}$ on a proposition $\mathrm{Q}$ metonymically connected with $\mathrm{P}$. In this part, we shall especially be concerned with Progressive meaning in the present.

When a speaker asserts that an event is in progress at $\mathrm{T}_{0}, \mathrm{~s} /$ he is not only saying that it has already started but also that is not completed yet. There is indeed an element of anticipation in the Progressive meaning. The question we may therefore feel entitled to ask is: "How does $\mathrm{s} /$ he know that the event is not finished at $\mathrm{T}_{0}$ ?". And the answer is: $\mathrm{s} / \mathrm{he}$ is just guessing. There can be no certain way for the speaker to know whether the event will carry on or not. This kind of guesswork therefore makes the Progressive meaning inherently subjective.

However, the speaker is not making any ungrounded claim. His/her anticipation of the continuation of the event is based on some evidence s/he as well as the hearer have access to. As we have seen, such evidence assumes propositional forms semantically contiguous to the proposition representing the event that is said to be in progress. Therefore, the reason why the Progressive meaning cannot be dissociated from metonymy is that representation of an event taking place at the present moment involves some kind of guesswork whose justification is to be found in the metonymic relationships between manifest contextual assumptions and the proposition that represents the event.

Let us now consider the generic use of the Progressive Present, as this will give us an opportunity to return to the sense of re-interpretation in the light of what has just been said.

\subsection{From metonymy to re-interpretation}

In fact, this use is both like and unlike other uses. What it has in common with other uses of the Progressive form is the underlying metonymic process. The speaker indeed relies on a proposition $Q$ that is manifest to the hearer (or presented as such) in order to assert $P$ whose relationship with $Q$ is one of contiguity. It is unlike other uses in the sense that this metonymic process seems to overshadow the aspectual function of the marker. The reason is that the generic context and the absence of an explicit reference point almost neutralises the opposition between the Progressive Present and the Simple Present. Yet, we have argued that traces of the Progressive meaning are reflected in the focus on the characteristics of the event rather than on its occurrence. But there is another difference between the Progressive and the Simple Present in that context. We are not going to repeat our analysis of (1), but let us briefly compare (1) with (9).

(1) So when you vote for a candidate, you are voting also to endorse the whole system. (www.progress.org/archive/fold128.htm)

(9) When you vote, you most importantly vote either to support our current system of privileges and barriers, or you can vote to let the walls come tumbling down. (www.progress.org/archive/fold128.htm)

In (1), $P$ is presented by the speaker as a side-effect of $Q$. And this claim is in fact highly subjective and controversial. It implies indeed that the voter is powerless and has no means of challenging the system. In (9), by contrast, although $\mathrm{Q}$ and the propositions (P1 and P2) expressed by the two coordinated clauses are semantically connected (owing to the syntactic structure of the sentence), the link is not metonymic, insofar as P1 and P2 refer to the only two possible alternatives offered to the voters. As a result, (9) is fairly 
uncontroversial, in that it makes the quite obvious statement, though not in so many words, that when you vote, you either vote for change or for continuity.

Therefore, we claim that there is more speaker involvement in (1) than in (9) because, unlike (9), (1) refers to two propositions which are metonymically connected.

\section{Conclusion}

To conclude, we have argued that the function of the Progressive Present can, in most cases, be analysed in aspectual terms, provided we take into account the role of two variables, namely: the meaning of the VP and the reference point. Adamczewski's criticism of descriptions based on aspect therefore appears to be ill-founded. Yet, there remain a few cases that cannot be accounted for in terms of progressiveness only, though we have argued that, even in such examples, aspect should not be totally dismissed. Another explanation, a more abstract one, had to be sought for.

But this is not the only reason why we have proposed that the use of BE + -ING is underlain by a cognitive process which consists in putting in relation two propositions that are metonymically related. In fact, we have emphasised that the Progressive meaning itself is dependent for its emergence on that cognitive process, so that it should be regarded not as an elementary particle of sense but as a complex semantic construct resulting from the cognitive activity of the speaker in relation to a specific context.

\section{BIBLIOGRAPHY}

Adamczewski, Henri. 1978. BE + ING dans la grammaire de l'anglais contemporain. Paris: Champion.

Adamczewski, Henri. 1982. La grammaire linguistique de l'anglais. Paris: Armand Colin.

Adamczewski, Henri. 1996. Genèse et développement d'une théorie linguistique. Paris : TILV.

Allen, Stannard. 1974. Living English Structure. London: Longman.

Austin, John. 1976. How to do things with words. Oxford: Oxford University Press.

Baldick, Chris. 1990. Oxford Concise Dictionary of Literary Terms. Oxford: Oxford University

Press.

Boisson, Claude. 2001. « 'Be + ing' et la théorie des phases d'Adamczewski : analyse dans un cadre de linguistique générale. » Anglophonia 10, 7-62.

Boisson, Claude. 2004. « Be + -ing de 'reprise' et be + -ing progressif: un modèle logique. »

Anglophonia 16, 55-70.

Brazil, David. 1994. Pronunciation for Advanced Learners of English. Cambridge: CUP.

Cohen, David. 1989. L'aspect verbal. Paris: PUF.

Comrie, Bernard. 1976. Aspect. Cambridge: CUP. 
Delmas, Claude. 2000. «BE \& -ING ou comment énoncer le recyclage de la relation 'partie/tout'. » Cycnos, vol.17, n Spécial, 173-185.

Furmaniak, Grégory. 2004. Influence des marqueurs aspectuels sur la construction et l'interprétation de la modalité dans les énoncés en MUST. Doctoral dissertation. University of Paris 3.

Furmaniak, Grégory. 2005. «Étude de quelques indices co-textuels contribuant à l'interprétation de MUST ». Congrès de la SAES, Toulouse, mai 2005.

Furmaniak, Grégory. 2005. "Is modality a kind of aspect ?" Workshop on Aspect and Aktionsart, Lisbon, October 2005.

Furmaniak, Grégory. A paraître. « Le modal MAY dans les phrases optatives : étude syntaxique, sémantique et pragmatique ». Anglophonia nº 18 .

Girard, Geneviève. 1998. « Aspect, choix sémiques, valeur de vérité ». Colloque CHRONOS, Valenciennes.

Grice, Paul. (1975) "Logic and conversation". In Cole \& Morgan (eds.). Syntax and Semantics 3: Speech Acts. New York: Academic Press. 41-58.

Groussier, Marie-Line. 2000. «La forme be + -ing, expression de la prédication de l'état de participation de l'actant principal (ou secondaire) à une occurrence du procès ». Cycnos, vol.17, n - Spécial, 189-202.

Halliday, M.A.K. \& Ruqaiya Hasan. 1976. Cohesion in English. London: Longman.

Joly, André and Dairine O'Kelly. 1990. Grammaire systématique de l'anglais. Paris : Nathan.

Kleiber, Georges. 1987. Du côté de la référence verbale. Les phrases habituelles. Berne : Peter Lang.

Lapaire, Jean-Rémi and Wilfrid Rotgé. 1993. Séminaire pratique de linguistique anglaise. Toulouse: Presses Universitaires du Mirail.

Leech, Geoffrey. 1987. Meaning and the English Verb. London: Longman.

Lyons, John. 1977. Semantics 2. Cambridge: CUP.

Mounin, Georges. 1995. Dictionnaire de la linguistique. ( $2^{\text {nd }}$ edition). Paris: PUF.

Nicaise, Alain and Mark Gray. 1998. L'intonation de l'anglais. Paris: Nathan.

Oxford Advanced Learners' Dictionary. ( $7^{\text {th }}$ edition). Oxford: Oxford University Press.

Palmer, Frank. 1974. The English Verb. London: Longman.

Recanati, Catherine and François. 1999. « La classification de Vendler revue et corrigée. » in Vogeleer, S. et al. (eds.). La modalité sous tous ses aspects. Amsterdam: Rodopi. 167-184.

Sperber, Dan and D. Wilson. 1995. Relevance. Oxford: Blackwell.

Vendler, Zeno. 1967. Linguistics in Philosophy. Ithaca: Cornell University Press.

\section{NOTES}

1. The originality of Adamczewski's theory was to link the syntactic properties of grammatical words with underlying mental processes yielding semantic constructs. Here, the nominalizing effect of the -ING morpheme is inseparable from its "cognitive" function.

2. Naturally, this assumption may be ill-founded.

3. For this, see Boisson (2001). 
4. Note that, unlike Adamczewski, we consider that the event is not referred to by the VP only, but by the subject and the VP.

5. With the notable exception of instantaneous events such as <kick> or <score>.

6. We make no distinction between the terms « state " and " property ".

7. It is worth noting that the French translation of (13) would be «Il fait l'idiot » with the verb faire $(=d o)$.

8. "A telic situation is one that involves a process that leads up to a well-defined terminal point, beyond which the process cannot continue" (Comrie 1976: 45).

9. An atelic event has no "terminal point, and can be protracted indefinitely or broken off at any point" (Comrie 1976: 44).

10. With the exception of instantaneous verbs. But of course, they are not used, in their usual sense, with BE + -ING.

11. The fact that the subject of the verb grow is non-agentive has, of course, something to do with it.

12. Note that with the adverbial this afternoon, the event <write a book> would not necessarily be viewed as discontinuous - which shows that, with telic or atelic events alike, the perception of a situation as continuous or discontinuous is dependent on the length of the temporal frame.

13. To be more precise, and to be consistent with our previous analysis of the activity denoted by write, we must say that C. \& F. Recanati (1999: 178) actually consider that atelic situations are "macro-homogeneous" but "micro-heterogeneous": “[les activités sont des] processus homogènes au niveau global, mais constitués par des processus localement hétérogènes". With regard to our example, this means that an occurrence of writing consists in the repetition of identical phases but that these phases can be broken down into smaller "bits" which are qualitatively different from one another.

14. We consider that the Simple Present can only refer to an event as a whole.

15. Unlike Vendler, however, we are talking about events, not "terms".

16. This opposition between the concepts of "occurrence" and "characteristics" is close to the quantitative/qualitative distinction made within Culioli's "Théorie des opérations énonciatives". See Groussier (2000:197). The quantitative dimension has to do with the existence or occurrence of a notion in a given situation, while the qualitative dimension is concerned with the conformity of a given occurrence with the notion.

17. To be accurate, we should speak of $\mathrm{Q} 1, \mathrm{Q} 2, \mathrm{Q} 3, \ldots, \mathrm{Qn}$, for it is clear, especially from example (25), that the speaker does not rely on just one single contextual assumption.

18. This point has already been made by Boisson (2001).

19. We shall ignore (24) as the issue is further complicated by the fact that the meaning of you're kidding/joking has become conventionalized to express surprise. For a detailed discussion of such examples, see Furmaniak 2004.

\section{ABSTRACTS}

We propose a unitary analysis of the English Progressive Present. Difficult as it may be to account for some of its uses in aspectual terms alone, we argue that referring to an event in progress at a given moment is the main function of the BE + -ING form. Yet, this meaning does not emerge out of the blue. It is a semantic construct resulting from a complex cognitive process. Our contention 
is that this underlying thought process (based on metonymy) can, in certain circumstances, take over the aspectual meaning without, however, deleting it completely.

L'objectif de cet article est de proposer une analyse unitaire du présent en BE + -ING. Bien qu'il soit difficile de rendre compte de tous les emplois de la périphrase en termes uniquement aspectuels, nous maintenons que sa fonction principale est de référer à un événement en cours à un moment donné. Toutefois, cette valeur n'est pas aussi simple qu'on pourrait le penser. Il s'agit en réalité d'une construction sémantique, fruit d'un processus cognitif complexe. Notre hypothèse est que ce processus cognitif sous-jacent, de nature métonymique, est susceptible, en certaines occasions, d'occulter la valeur aspectuelle sans toutefois l'annuler totalement.

\section{INDEX}

Mots-clés: $\mathrm{BE}+-\mathrm{ING}$, aspect, progressive, metonymy, re-interpretation

Keywords: $\mathrm{BE}+-\mathrm{ING}$, aspect, progressif, métonymie, ré-interprétation.

\section{AUTHOR}

\section{GRÉGORY FURMANIAK}

Université de Reims Champagne-Ardennes 